\title{
Erratum
}

\section{Erratum to "Beyond the Definitions of the Phenotypic Complications of Sickle Cell Disease: An Update on Management"}

\author{
Samir K. Ballas, ${ }^{1}$ Muge R. Kesen, ${ }^{2}$ Morton F. Goldberg, ${ }^{2}$ Gerard A. Lutty, ${ }^{2}$ \\ Carlton Dampier, ${ }^{3}$ Ifeyinwa Osunkwo, ${ }^{3}$ Winfred C. Wang, ${ }^{4}$ Carolyn Hoppe, ${ }^{5}$ \\ Ward Hagar, ${ }^{5}$ Deepika S. Darbari, ${ }^{6}$ and Punam Malik ${ }^{7}$ \\ ${ }^{1}$ Cardeza Foundation and Department of Medicine, Thomas Jefferson University, 1015 Walnut Street, Philadelphia, PA 19107, USA \\ ${ }^{2}$ Wilmer Ophthalmological Institute, Johns Hopkins Hospital, 400 North Broadway, Baltimore, MD 21267, USA \\ ${ }^{3}$ Department of Pediatrics, Aflac Cancer Center and Blood Disorders Service, Children's Healthcare of Atlanta, \\ Emory University School of Medicine, Atlanta, GA 30322, USA \\ ${ }^{4}$ Department of Hematology, St. Jude Children's Research Hospital, Memphis, TN 38105, USA \\ ${ }^{5}$ Children's Hospital \& Research Center at Oakland, 744 52nd Street, Oakland, CA 94609, USA \\ ${ }^{6}$ Division of Hematology, Children's National Medical Center, 111 Michigan Avenue, N.W., Washington, DC 20010, USA \\ ${ }^{7}$ Cincinnati Children's Hospital Medical Center, Cincinnati, OH 45229, USA \\ Correspondence should be addressed to Samir K. Ballas; samir.ballas@jefferson.edu
}

Received 7 December 2012; Accepted 20 December 2012

Copyright (C) 2013 Samir K. Ballas et al. This is an open access article distributed under the Creative Commons Attribution License, which permits unrestricted use, distribution, and reproduction in any medium, provided the original work is properly cited.

Reference number [481] is inaccurate and should be replaced by the following two references:

[481a] L. A. Styles, M. Abboud, S. Larkin, M. Lo, and F. A. Kuypers, "Transfusion prevents acute chest syndrome predicted by elevated secretory phospholipase A2," British Journal of Haematology, vol. 136, no. 2, pp. 343344, 2007.

[481b] T. Scott Miller, E. Wright, M. Abboud et al., "Impact of chronic transfusion on incidence of pain and acute chest syndrome during the Stroke Prevention Trial (STOP) in sickle-cell anemia," Journal of Pediatrics, vol. 139, no. 6, pp. 785-789, 2001. 


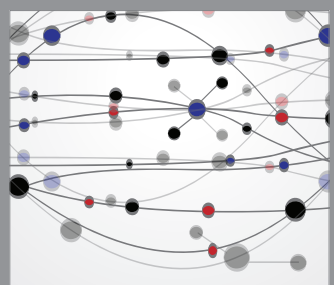

The Scientific World Journal
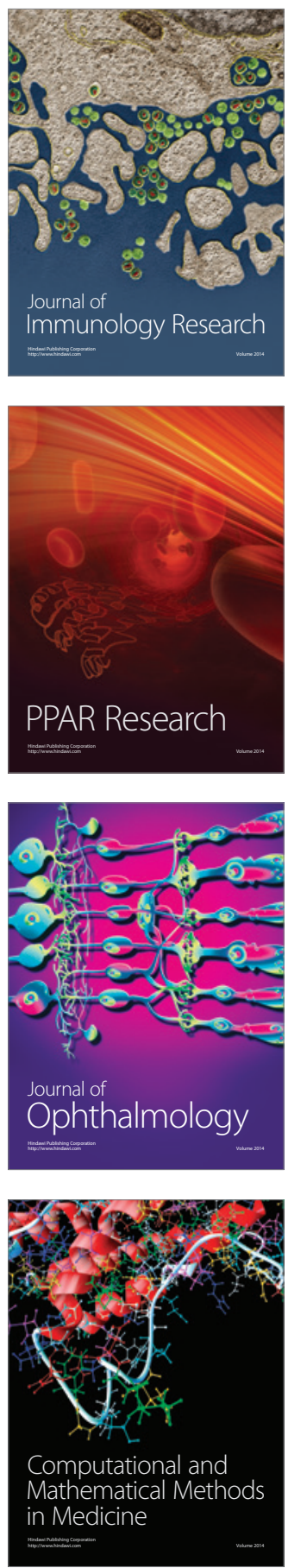

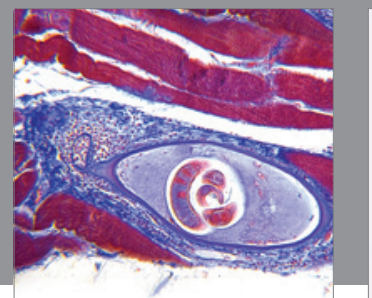

Gastroenterology

Research and Practice
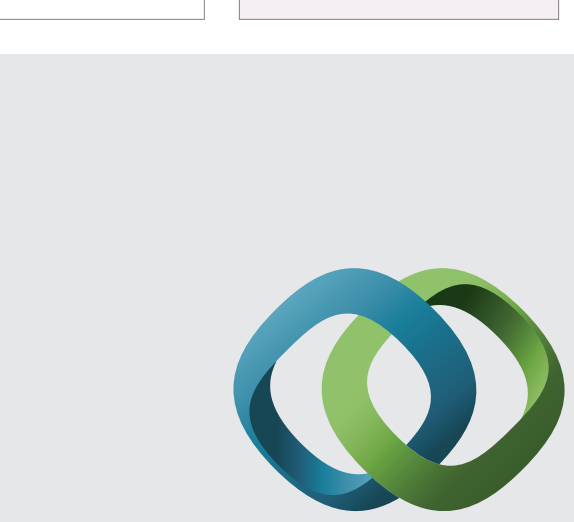

\section{Hindawi}

Submit your manuscripts at

http://www.hindawi.com
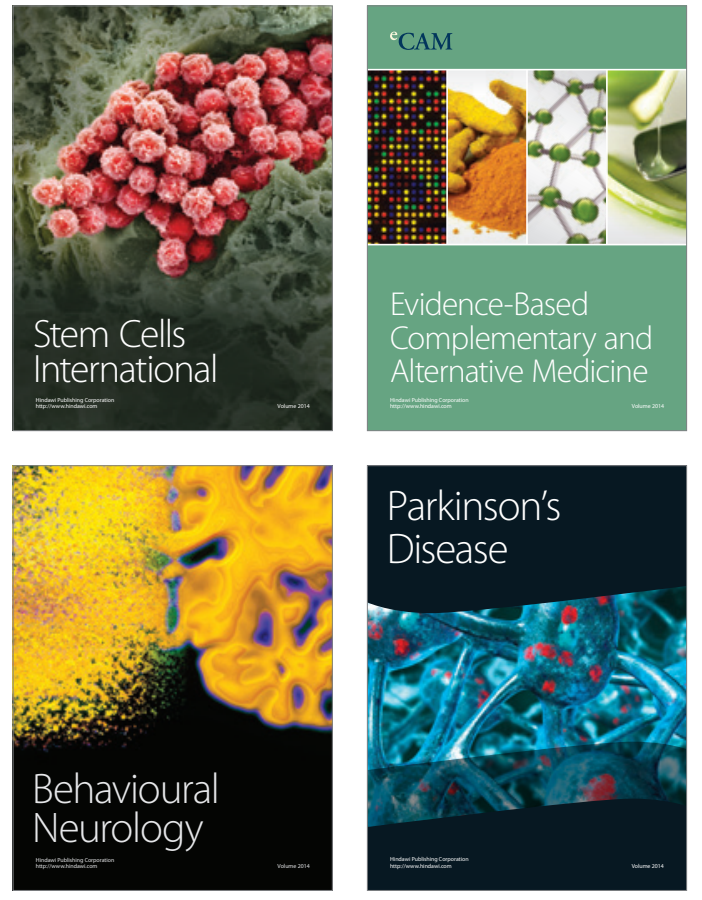
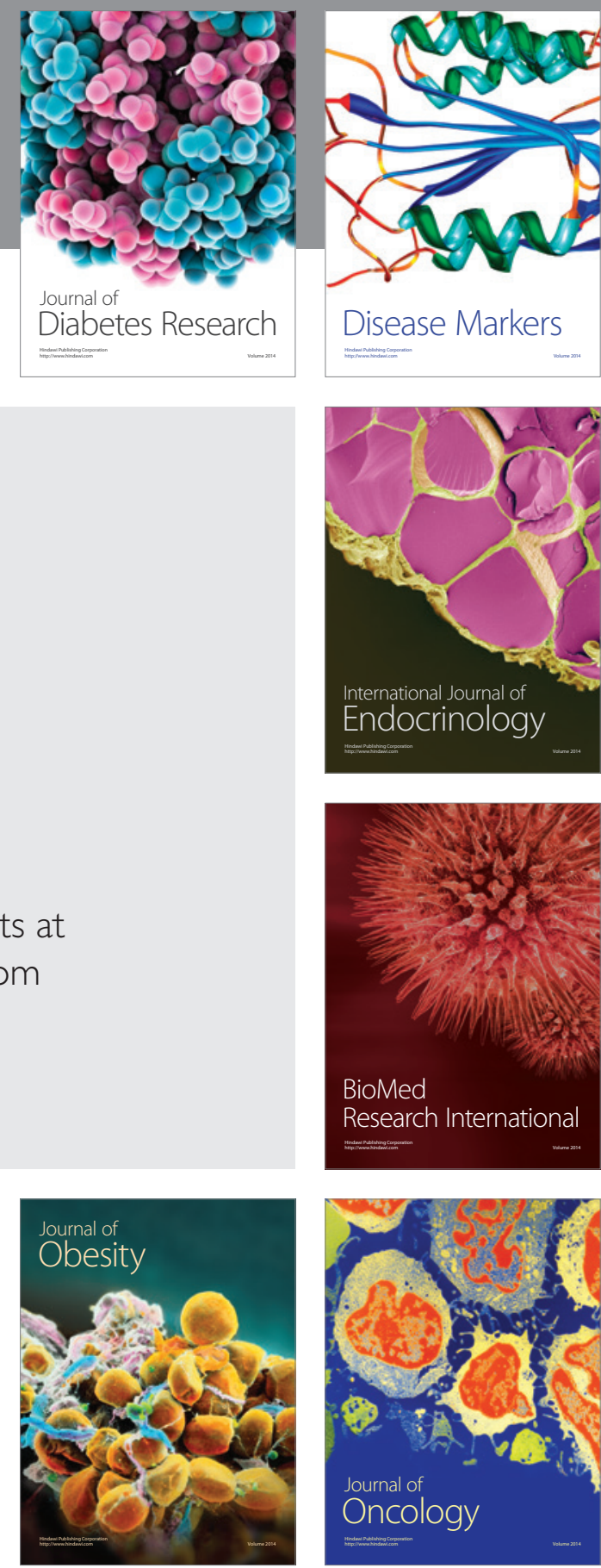

Disease Markers
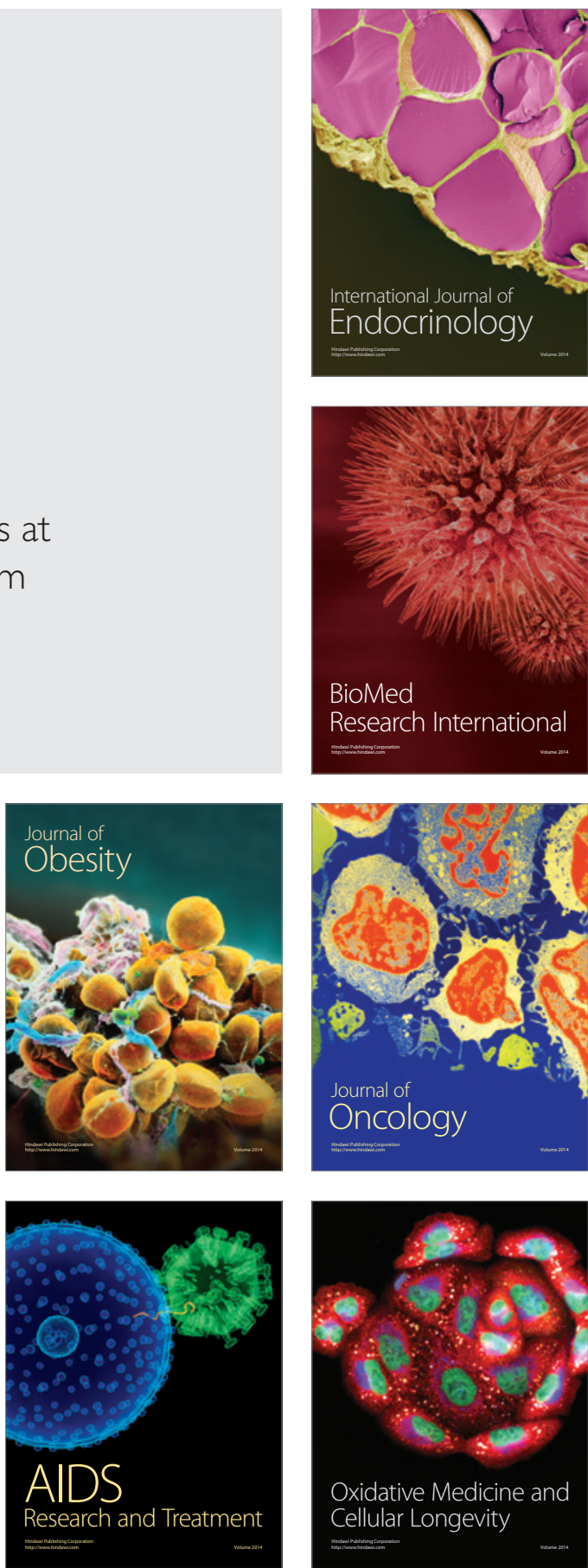